\title{
Prenylated Coumarins, Chalcone and New Cinnamic Acid and Dihydrocinnamic Acid Derivatives from Brosimum gaudichaudii
}

\author{
Verônica de F. F. Monteiro, Leda Mathias*, Ivo J. C. Vieira, Jan Schripsema and \\ Raimundo Braz-Filho
}

\author{
Setor de Química de Produtos Naturais - LCQUI - CCT, Universidade Estadual do Norte Fluminense, 28015-620, \\ Campos - RJ, Brazil
}

\begin{abstract}
Três novos derivados naturais dos ácidos cinâmico e diidrocinâmico foram isolados das raízes de Brosimum gaudichaudii, além de mais quatorze substâncias naturais conhecidas (dez cumarinas, uma chalcona, os dois esteróides $\beta$-sitosterol e $3 \beta$ - $O-\beta$-D-glicopiranosil- $\beta$-sitosterol e o triterpeno $\beta$ amirina). As estruturas destas substâncias foram estabelecidas com base na análise de dados espectrais, inclusive experiências de RMN 2D e espectros de massas. O ácido 4-hidroxi-3-prenilcinâmico pode ser postulado como precursor para todas substancias aromáticas. As novas substâncias naturais são derivadas do precursor das cumarinas que perdeu a possibilidade de formar o anel lactônico devido a $O$-metilação.
\end{abstract}

Three new natural cinnamic acid and dihydrocinnamic acid derivatives were isolated from the roots of Brosimum gaudichaudii, in addition to fourteen known substances (ten coumarins, one chalcone, $\beta$-sitosterol, $3 \beta$ - $O-\beta$-D-glucopyranosylsitosterol and $\beta$-amyrin). The structures were established by spectral data, including analysis of $2 \mathrm{D}-\mathrm{NMR}$ experiments and mass spectra. All aromatic compounds have 4-hydroxy-3-prenylcinnamic acid as a common precursor. The new substances are derived from a precursor of the coumarins, which through an O-methylation lost its ability to form the lactone ring.

Keywords: Brosimum gaudichaudii, Moraceae, Coumarins, Chalcone, Cinnamic acid and dihydrocinnamic acid derivatives

\section{Introduction}

In previous reports, ${ }^{1-3}$ the isolation of the coumarins gaudichaudine (1), xanthyletin (2), luvangetin (3), psoralen (4), bergapten (5) and (+)-(2' $\left.S, 3^{\prime} R\right)-1^{\prime}$-hydroxymarmesin (6) from extracts of the root bark of Brosimum gaudichaudii Trécul., Moraceae, was described.

In this paper, we report the isolation of eleven additional compounds, eight known substances, and three new cinnamic acid derivatives: 3-(7-methoxy-2,2-dimethyl$2 H$-6-chromenyl)-(E)-propenoic acid (7), 3-(7-methoxy2,2-dimethyl-2H-6-chromenyl)propanoic acid (8) and 3(6-methoxybenzo[b]furan-5-yl)propanoic acid (9). The known substances are the coumarins marmesin (10), 1', 2'dehydromarmesin (11), 8-methoxymarmesin (12) and 1'hydroxy-3'- $O$ - $\beta$-glucopyranosylmarmesin (13), the chalcone 2',4',4-trihydroxy-3',3-diprenylchalcone (14), the steroids $\beta$-sitosterol and $3 \beta$-O- $\beta$-D-glucopyranosyl-

* e-mail: mathias@uenf.br sitosterol (daucosterol) and the triterpene $\beta$-amyrin. All substances were isolated from the roots of this species.

The genus Brosimum, which is traditionally employed in the photochemotherapy of psoriasis, ${ }^{4,5}$ is known for the production of prenylated coumarins, ${ }^{6-8}$ including furanocoumarins. These linear furanocoumarins, also known as psoralens (e.g. 4 and 5), are widely distributed in plants and have also been used internally and externally to promote skin pigmentation and skin tanning. Methoxysalen (xanthotoxin=8-methoxypsoralen) is used in medicine to facilitate skin repigmentation in patients affected by severe vitiligo. ${ }^{9}$

\section{Results and Discussion}

The known natural products marmesin (10), 1',2'dehydromarmesin (11), 8-methoxymarmesin (12), 1'hydroxy-3'- $O-\beta$-glucopyranosylmarmesin (13) and 2',4',4trihydroxy-3',3-diprenylchalcone (kanzonol C, 14) were identified through their ${ }^{1} \mathrm{H}$ and ${ }^{13} \mathrm{C}$ NMR spectral data, 
<smiles>CC(C)=C1Oc2cc3oc(=O)ccc3cc2C1=O</smiles>

1<smiles>[R]c1c2c(cc3ccc(=O)oc13)C=C[C@@H](C)O2</smiles>

$2 \mathrm{R}=\mathrm{H}$

$3 \mathrm{R}=\mathrm{OMe}$<smiles>[R]c1c2ccoc2cc2oc(=O)ccc12</smiles><smiles>COc1cc2c(cc1CCC(=O)O)C=C[C@@H](C)O2</smiles><smiles>[R]Oc1cc2occc2cc1CCC(=O)OCC</smiles><smiles>CC(C)(O)c1cc2cc3ccc(=O)oc3cc2o1</smiles>

$9 \mathrm{R}=\mathrm{Me}, \mathrm{R}^{\prime}=\mathrm{H}$

9a $\mathrm{R}=\mathrm{Glc}, \mathrm{R}^{\prime}=\mathrm{H}$<smiles>[R]c1c2c(cc3ccc(=O)oc13)C([R])[C@H](C([R20])(C)C)O2</smiles>

9b $\mathrm{R}=\mathrm{Glc}, \mathrm{R}^{\prime}=\mathrm{Me}$

$$
\begin{array}{ll}
6 & R=R^{2}=H, R^{1}=O H \\
10 & R=R^{1}=R^{2}=H \\
12 & R=O M e, R^{1}=R^{2}=H \\
\text { 13 } & R=H, R^{1}=O H, R^{2}=\text { Glc } \\
\text { 13a } & R=H, R^{1}=O H, R^{2}={\text { Glc- }-A_{4}}_{4}
\end{array}
$$

including the comparison with literature values for $\mathbf{1 0},,^{10,11}$ $\mathbf{1 1},{ }^{12} \mathbf{1 2}$, named rutaretin methyl ether, ${ }^{13} \mathbf{1 3}^{14}$ and $\mathbf{1 4} .{ }^{15}$ The new peracetyl derivative 13a was also used to confirm the structure of 13 and to obtain the complete ${ }^{1} \mathrm{H}$ and ${ }^{13} \mathrm{C}$ NMR chemical shift assignments (see Experimental). The terpenoids $\beta$-sitosterol and $\beta$-amyrin were identified by direct comparison with authentic samples. $3 \beta-\mathrm{O}-\beta$-Dglucopyranosylsitosterol was characterized by ${ }^{1} \mathrm{H}$ and ${ }^{13} \mathrm{C}$ NMR spectral data, including the data of its peracetyl derivative, and comparison with literature values. ${ }^{16}$

The multiplicity of each carbon of the components present in the mixture of the cinnamic acid derivatives 3(7-methoxy-2,2-dimethyl-2H-6-chromenyl)-(E)-propenoic acid (7), 3-(7-methoxy-2,2-dimethyl-2H-6-chromenyl) propanoic acid (8) and 3-(6-methoxybenzo[b]furan-5yl)propanoic acid (9) was deduced from the analysis of the HBBD- and DEPT- ${ }^{13} \mathrm{C}$ NMR (125 MHz) spectra (Table 1). This analysis in combination with the ${ }^{1} \mathrm{H}$ NMR and low resolution mass spectra $\left(\mathrm{m} / \mathrm{z} 260,66.2 \%,[\mathrm{M}]^{+}\right.$of $\mathbf{7}$, $\mathrm{C}_{15} \mathrm{H}_{16} \mathrm{O}_{4} ; \mathrm{m} / z 262,39.5 \%$, [M] ${ }^{++}$of $8, \mathrm{C}_{15} \mathrm{H}_{18} \mathrm{O}_{4} ; 220,60.8 \%$, $[\mathrm{M}]^{++}$of $\left.9, \mathrm{C}_{12} \mathrm{H}_{12} \mathrm{O}_{4}\right)$ allowed the deduction of the expanded molecular formulas: $(\mathrm{C})_{5}(\mathrm{COOH})(\mathrm{CH})_{6}\left(\mathrm{CH}_{3}\right)_{2}$ $(\mathrm{OMe})(\mathrm{O})$ for $7,(\mathrm{C})_{5}(\mathrm{COOH})(\mathrm{CH})_{4}\left(\mathrm{CH}_{2}\right)_{2}\left(\mathrm{CH}_{3}\right)_{2}(\mathrm{OMe})(\mathrm{O})$ for 8 and $(\mathrm{C})_{4}(\mathrm{COOH})(\mathrm{CH})_{4}\left(\mathrm{CH}_{2}\right)_{2}(\mathrm{OMe})(\mathrm{O})$ for 9 (Table 1). On the basis of the relative intensities of the singlet signals corresponding to $\mathrm{H}-5$ (7/8: $\left.\delta_{\mathrm{H}} 7.13 / 6.74\right)$ and $\mathrm{H}-4$ $\left(9 \delta_{\mathrm{H}} 7.33\right)$ in the ${ }^{1} \mathrm{H}$ NMR spectrum $(500 \mathrm{MHz})$ the percentages of $\mathbf{7}(43.9 \%), \mathbf{8}(13.8 \%)$ and $\mathbf{9}(42.3 \%)$ in the mixture were calculated. The composition of the mixture was confirmed by GC/EIMS analysis: 7 yielded a peak at
$\mathrm{Rt}=33.95 \mathrm{~min}$, with the molecular ion at $\mathrm{m} / \mathrm{z} 260,8$ at $\mathrm{Rt}$ $=29.33 \mathrm{~min}$, with the molecular ion at $\mathrm{m} / z 262$, and $\mathbf{9}$ at Rt $=25.40 \mathrm{~min}$, with the molecular ion at $\mathrm{m} / \mathrm{z} 220$ (Scheme 1).

The presence of a 6-substituted 7-methoxy-2,2dimethyl-2H-chromenyl moiety $\left[(\mathrm{C})_{5}(\mathrm{CH})_{4}\left(\mathrm{CH}_{3}\right)_{2}(\mathrm{OMe}) \mathrm{O}\right.$ $\left.=\mathrm{C}_{12} \mathrm{H}_{13} \mathrm{O}_{2}\right]$ in the compounds $7(43.9 \%)$ and $\mathbf{8}(13.8 \%)$ was recognized by signals corresponding to $\mathrm{H}-8\left[\mathbf{7 / 8}: \delta_{\mathrm{H}}\right.$

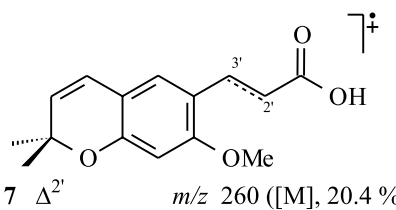

82 ',3'-dihydro $m / z$ 262 ([M], $17.3 \%)$

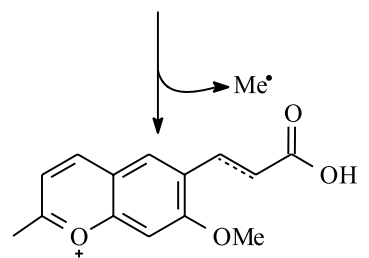

$$
7 \Delta^{2^{\prime}} \quad m / z 245(100 \%)
$$

8 2',3'-dihydro $\mathrm{m} / \mathrm{z} 247$ (100\%)

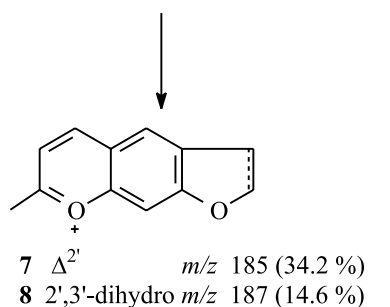<smiles>COc1cc2occc2cc1CCC(=O)O</smiles>

$9 \mathrm{~m} / \mathrm{z} 220(42.8 \%)$

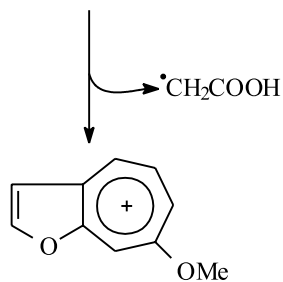

$m / z 161(100 \%)$

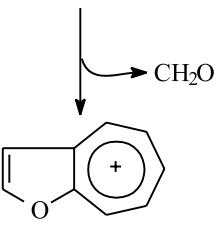

$m / z 131(60.9 \%)$
Scheme 1. Proposed fragmentation patterns for 7, 8 and 9 (only peaks classified as principals) 
Table 1. ${ }^{1} \mathrm{H}(400 \mathrm{MHz})$ and ${ }^{13} \mathrm{C}(125 \mathrm{MHz})$ NMR spectral data for the mixture of $\mathbf{7}, \mathbf{8}$ and $\mathbf{9}$, in $\mathrm{CDCl}_{3}$. Chemical shifts in $\delta\left(\delta_{\mathrm{H}}\right.$ and $\left.\delta_{\mathrm{C}}\right)$ and coupling constants $\left(J\right.$, in parentheses) in $\mathrm{Hz}^{*}$

\begin{tabular}{|c|c|c|c|c|c|c|}
\hline & \multicolumn{2}{|c|}{7} & \multicolumn{2}{|c|}{8} & \multicolumn{2}{|c|}{9} \\
\hline & $\delta_{\mathrm{C}}$ & $\delta_{\mathrm{H}}$ & $\delta_{\mathrm{C}}$ & $\delta_{\mathrm{H}}$ & $\delta_{\mathrm{C}}$ & $\delta_{\mathrm{H}}$ \\
\hline \multicolumn{7}{|l|}{$\mathbf{C}$} \\
\hline 1 , & 172.82 & - & 178.93 & - & 178.93 & - \\
\hline 2 & 77.50 & - & 77.28 & - & - & - \\
\hline 5 & - & - & - & - & 124.75 & - \\
\hline 6 & 114.31 & - & 120.56 & - & 155.93 & - \\
\hline 7 & 160.16 & - & 158.28 & - & - & - \\
\hline 8 & - & - & - & - & 154.91 & - \\
\hline 9 & 157.05 & - & 152.83 & - & 119.91 & - \\
\hline 10 & 115.89 & - & 113.68 & - & - & - \\
\hline \multicolumn{7}{|l|}{$\mathrm{CH}$} \\
\hline 2 & - & - & - & - & 143.79 & $7.49(\mathrm{~d}, 2.0)$ \\
\hline 2 & 114.50 & $6.34(\mathrm{~d}, 16.0)$ & - & - & - & - \\
\hline 3 & 128.55 & $5.51(\mathrm{~d}, 9.8)$ & 126.61 & $5.42(\mathrm{~d}, 9.8)$ & 106.25 & $6.64(\mathrm{~d}, 2.0)$ \\
\hline 3 , & 142.28 & $7.97(\mathrm{~d}, 16.0)$ & - & - & - & - \\
\hline 4 & 121.34 & $6.26(\mathrm{~d}, 9.8)$ & 121.91 & $6.22(\mathrm{~d}, 9.8)$ & 121.31 & $7.33(\mathrm{~s})$ \\
\hline 5 & 127.10 & $7.13(\mathrm{~s})$ & 127.47 & $6.74(\mathrm{~s})$ & - & - \\
\hline 7 & - & - & - & - & 94.14 & $6.99(\mathrm{~s})$ \\
\hline 8 & 99.86 & $6.36(\mathrm{~s})$ & 99.54 & $6.32(\mathrm{~s})$ & - & - \\
\hline \multicolumn{7}{|l|}{$\mathrm{CH}_{2}$} \\
\hline 2 , & - & - & 34.23 & $2.60(\mathrm{t}, 8.0)$ & 34.33 & $2.67(\mathrm{t}, 7.6)$ \\
\hline 3 & - & - & 25.27 & $2.82(\mathrm{t}, 8.0)$ & 26.32 & $3.00(\mathrm{t}, 7.6)$ \\
\hline \multicolumn{7}{|l|}{$\mathrm{CH}_{3}$} \\
\hline $4^{\prime}, 5$, & 28.37 & $1.43(\mathrm{~s})$ & 28.05 & $1.40(\mathrm{~s})$ & - & - \\
\hline $\mathrm{MeO}-6$ & - & - & - & - & 55.59 & $3.83(\mathrm{~s})$ \\
\hline $\mathrm{MeO}-7$ & 56.70 & $3.84(\mathrm{~s})$ & 55.38 & $3.75(\mathrm{~s})$ & - & - \\
\hline
\end{tabular}

*Multiplicity of carbon signals deduced by comparative analysis of HBBD- and DEPT- ${ }^{13} \mathrm{C}$ NMR spectra. Homonuclear $2 \mathrm{D}{ }^{1} \mathrm{H}-{ }^{1} \mathrm{H}-\mathrm{COSY}$ and heteronuclear HMQC and HMBC (Table 2) spectra were also used in these assignments. Chemical shifts and coupling constants $(J)$ obtained from 1D ${ }^{1} \mathrm{H}$ NMR spectrum

Table 2. Heteronuclerar long-range coupling of ${ }^{1} \mathrm{H}^{-13} \mathrm{C}$ for the mixture of $\mathbf{7}, \mathbf{8}$ and $\mathbf{9}$ observed in $\mathrm{HMBC}$ spectrum, in $\mathrm{CDCl}_{3}{ }^{*}$

\begin{tabular}{|c|c|c|c|c|c|c|}
\hline & \multicolumn{2}{|c|}{7} & \multicolumn{2}{|c|}{8} & \multicolumn{2}{|c|}{9} \\
\hline & ${ }^{2} J_{\mathrm{CH}}$ & ${ }^{3} J_{\mathrm{CH}}$ & ${ }^{2} J_{\mathrm{CH}}$ & ${ }^{3} J_{\mathrm{CH}}$ & ${ }^{2} J_{\mathrm{CH}}$ & ${ }^{3} J_{\mathrm{CH}}$ \\
\hline \multicolumn{7}{|l|}{$\mathbf{C}$} \\
\hline 1 , & $\mathrm{H}-2$, & H-3, & $2 \mathrm{H}-2^{\prime}$ & $2 \mathrm{H}-3^{\prime}$ & $2 \mathrm{H}-2^{\prime}$ & $2 \mathrm{H}-3^{\prime}$ \\
\hline 2 & H-3 $3 \mathrm{H}^{\prime}-4^{\prime} / 3 \mathrm{H}-5$ & $\mathrm{H}-4$ & H-3 $3 \mathrm{H}-4$ '/3H-5, & $\mathrm{H}-4$ & - & - \\
\hline 5 & - & - & - & - & $2 \mathrm{H}-3$, & $\mathrm{H}-7 \quad 2 \mathrm{H}-2$ \\
\hline 6 & $\mathrm{H}-3$, & & $2 \mathrm{H}-3$ & $\mathrm{H}-8 \quad 2 \mathrm{H}-2$ & & '2H-3’ MeO-6 \\
\hline 7 & H- 8 & H-5 H-3' MeO-7 & H- 8 & $2 \mathrm{H}-3$ ' $\mathrm{MeO}-7$ & - & - \\
\hline 8 & - & - & - & - & $\mathrm{H}-7$ & H-2, H-3, H-4 \\
\hline 9 & $\mathrm{H}-8$ & $\mathrm{H}-4 \mathrm{H}-5$ & $\mathrm{H}-8$ & $\mathrm{H}-5$ & $\mathrm{H}-4$ & H-3 H-8 \\
\hline 10 & $\mathrm{H}-4$ & $\mathrm{H}-3$ & $\mathrm{H}-5$ & H-3 H-8 & - & - \\
\hline \multicolumn{7}{|l|}{$\mathbf{C H}$} \\
\hline 3 & & & & & $\mathrm{H}-2$ & \\
\hline 3, & & & & & & $\mathrm{H}-4$ \\
\hline 4 & & $\mathrm{H}-5$ & & & & \\
\hline 5 & & H-3' H-4 & & $2 \mathrm{H}-3^{\prime}$ & - & - \\
\hline \multicolumn{7}{|l|}{$\mathrm{CH}_{2}$} \\
\hline 2 , & & & $2 \mathrm{H}-3^{\prime}$ & & $2 \mathrm{H}-3$, & \\
\hline $3^{\prime}$ & & & $2 \mathrm{H}-2$ & $\mathrm{H}-5$ & $2 \mathrm{H}-2^{\prime}$ & \\
\hline \multicolumn{7}{|l|}{$\mathrm{CH}_{3}$} \\
\hline $4^{\prime}, 5^{\prime}$ & & $\mathrm{H}-3$ & & & & \\
\hline
\end{tabular}

* Multiplicity of carbon signals deduced by comparative analysis of HBBD- and DEPT- ${ }^{13} \mathrm{C}$ NMR spectra. Homonuclear $2 \mathrm{D}{ }^{1} \mathrm{H}-{ }^{1} \mathrm{H}-\mathrm{COSY}$ and heteronuclear HMQC (Table 1) spectra were also used in these assignments 
6.36/6.32 (s)], H-5 [7/8: $\delta_{\mathrm{H}}$ 7.13/6.74 (s)], H-4 [7/8: $\delta_{\mathrm{H}}$ 6.26/6.22 (d, $J 9.8 \mathrm{~Hz})], \mathrm{H}-3$ [7/8: $\delta_{\mathrm{H}} 5.51 / 5.42(\mathrm{~d}, J 9.8$ $\mathrm{Hz})]$, the methyl groups at C-2 [7/8: $\left.\delta_{\mathrm{H}} 1.43 / 1.40(\mathrm{~s})\right]$ and the methoxyl at C-7 [7/8: $\left.\delta_{\mathrm{H}} 3.84 / 3.75(\mathrm{~s})\right]$ observed in the ${ }^{1} \mathrm{H}$ NMR spectrum of the mixture (Table 1). This deduction was confirmed by the ${ }^{13} \mathrm{C}$ NMR spectrum (Table 1 ). The location of a methoxy group at carbon atom $\mathrm{C}-7$ of the chromenyl moiety was confirmed by HMBC correlations after the unambiguous assignment of the chemical shifts of the directly bound $\mathrm{CH}$ pairs by cross-peaks observed in the HMQC spectrum (Table 1), such as hydrogen atoms $\mathrm{H}-$ 5 [7/8: $\left.\delta_{\mathrm{H}} 7.13 / 6.74(\mathrm{~s})\right]$ and $\mathrm{H}-8$ [7/8: $\left.\delta_{\mathrm{H}} 6.36 / 6.32(\mathrm{~s})\right]$ and the corresponding carbon atoms C-5 (7/8: $\delta_{\mathrm{C}} 127.10 /$ 127.47) and C-8 (7/8: $\left.\delta_{\mathrm{C}} 99.86 / 99.54\right)$. In the HMBC spectrum (Table 2) the following correlations established the location of the methoxyl group: a) correlation of H-8 [7/8: $\left.\delta_{\mathrm{H}} 6.36 / 6.32(\mathrm{~s})\right]$ with both oxygenated carbons C-7 (7/8: $\left.\delta_{\mathrm{C}} 160.16 / 158.28,{ }^{2} J_{\mathrm{CH}}\right)$ and C-9 (7/8: $\delta_{\mathrm{C}} 157.05 /$ $152.83,{ }^{2} J_{\mathrm{CH}}$; b) correlation of H-5 [7/8: $\left.\delta_{\mathrm{H}} 7.13 / 6.74(\mathrm{~s})\right]$ with both C-7 and C-9; c) correlation of MeO-7 [7/8: $\delta_{\mathrm{H}}$ 3.84/3.75 (s)] with C-7; and d) correlation of $\mathrm{H}-4$ [7/8: $\delta_{\mathrm{H}}$ $6.26 / 6.22$ (d, $J 9.8 \mathrm{~Hz}$ )] with C-9, along with other data summarized in Table 2. Thus, the difference of 2 daltons observed between the molecular ions of $7\left(\mathrm{~m} / z 260,[\mathrm{M}]^{+}\right.$, $\left.\mathrm{C}_{15} \mathrm{H}_{16} \mathrm{O}_{4}\right)$ and of $8\left(\mathrm{~m} / z 262,\left([\mathrm{M}]^{+}, \mathrm{C}_{15} \mathrm{H}_{18} \mathrm{O}_{4}\right)\right.$ was attributed to the presence of 6-propenoic acid $\left(\mathrm{C}_{3} \mathrm{H}_{5} \mathrm{O}_{2}=\mathrm{C}_{15} \mathrm{H}_{18} \mathrm{O}_{4}\right.$ $\left.\mathrm{C}_{12} \mathrm{H}_{13} \mathrm{O}_{2}\right)$ and 6-propanoic acid $\left(\mathrm{C}_{3} \mathrm{H}_{3} \mathrm{O}_{2}=\mathrm{C}_{15} \mathrm{H}_{16} \mathrm{O}_{4}\right.$ $\mathrm{C}_{12} \mathrm{H}_{13} \mathrm{O}_{2}$ ) moieties, respectively. The signals corresponding to these moieties, observed in the ${ }^{1} \mathrm{H}$ NMR spectrum (Table 1), were attributed to $2 \mathrm{H}-3^{\prime} / \mathrm{H}-3^{\prime}\left[\mathbf{8} / 7: \delta_{\mathrm{H}} 2.82(\mathrm{t}, J\right.$ $8.0 \mathrm{~Hz}) / 7.97\left(\mathrm{~d}, J 16.0 \mathrm{~Hz}, E\right.$-configuration) and $2 \mathrm{H}-2^{\prime} / \mathrm{H}-$ 2' [8/7: $\delta_{\mathrm{H}} 2.60(\mathrm{t}, J 8.0 \mathrm{~Hz}) / 6.34(\mathrm{~d}, J 16.0 \mathrm{~Hz}, E-$ configuration). Through correlations in the ${ }^{1} \mathrm{H}-{ }^{13} \mathrm{C}-\mathrm{HMQC}-$ ${ }^{1} J_{\mathrm{CH}}$ spectrum (Table 1) the corresponding carbon signals were identified: $\mathrm{CH}_{2}-3^{\prime} / \mathrm{CH}-3$ ' $\left(8 / 7: \delta_{\mathrm{C}} 25.27 / 142.28\right)$ and $\mathrm{CH}_{2}-2^{\prime} / \mathrm{CH}-2$ ' (8/7: $\left.\delta_{\mathrm{C}} 34.23 / 114.50\right)$. Thus, the structures of these two new benzopyran derivatives were determined as 3-(7-methoxy-2,2-dimethyl-2H-6-chromenyl)-(E)propenoic acid (7) and 3-(7-methoxy-2,2-dimethyl-2H-6chromenyl)-propanoic acid (8). The complete ${ }^{1} \mathrm{H}$ and ${ }^{13} \mathrm{C}$ chemical shift assignments of these natural products, as derived from the homonuclear $2 \mathrm{D}{ }^{1} \mathrm{H}-{ }^{1} \mathrm{H}-\mathrm{COSY}$ and heteronuclear $2 \mathrm{D}{ }^{1} \mathrm{H}-{ }^{13} \mathrm{C}$ shift-correlated (HMQC and HMBC) experiments, are summarized in Table 2.

The remaining signals observed in ${ }^{1} \mathrm{H}$ and ${ }^{13} \mathrm{C}$ NMR (Tables 1 and 2) and mass $\left(\mathrm{m} / \mathrm{z} 220,60.8 \%,[\mathrm{M}]^{+}, \mathrm{C}_{12} \mathrm{H}_{12} \mathrm{O}_{4}\right.$ ) spectra were used to establish structure $9\left[(\mathrm{C})_{4}(\mathrm{COOH})\right.$ $\left.(\mathrm{CH})_{4}\left(\mathrm{CH}_{2}\right)_{2}(\mathrm{OMe})(\mathrm{O})\right]$ for the third component $(42.3 \%)$ present in the mixture. The additional signals reported in the ${ }^{1} \mathrm{H}$ NMR spectrum (Table 1 ) were used to characterize the 5-substituted 6-methoxybenzofuran unit $\left[\delta_{\mathrm{H}} 6.99(\mathrm{~s})\right.$,
H-7; 7.33 (s), H-4; 6.64 (d, J 2.0 Hz), H-3; 7.49 (d, J 2.0 Hz), $\mathrm{H}-2]$ and the linked propanoic acid moiety $\left[\delta_{\mathrm{H}} 3.00(\mathrm{t}, J\right.$ $\left.7.6 \mathrm{~Hz}, 2 \mathrm{H}-3^{\prime}\right)$ and $\delta_{\mathrm{H}} 2.67\left(\mathrm{t}, J 7.6 \mathrm{~Hz}, 2 \mathrm{H}-2^{\prime}\right)$ ) of structure 9. Through the correlations in the HMQC spectrum (Table 1) the corresponding signals of the carbon atoms were found at $\delta_{\mathrm{C}} 94.14(\mathrm{C}-7), 121.31(\mathrm{C}-4), 106.25(\mathrm{C}-3), 143.79$ (C-2), 26.32 (C-3') and 34.33 (C-2'). Additional analysis of the ${ }^{1} \mathrm{H}$ and ${ }^{13} \mathrm{C}$ NMR spectra, including the homonuclear $2 \mathrm{D}^{1} \mathrm{H}-{ }^{1} \mathrm{H}-\mathrm{COSY}$ and heteronuclear $2 \mathrm{D}^{1} \mathrm{H}-{ }^{13} \mathrm{C}$ shift-correlated spectra (Table 2), was used to confirm structure 9 and to assign all ${ }^{1} \mathrm{H}$ and ${ }^{13} \mathrm{C}$ chemical shifts unambiguously. Thus, the structure of the third component was defined as 3-(6-methoxybenzo[b]furan-5-yl)propanoic acid (9), a new natural product.

Compound 7 (chromenylacrylic acid) was reported as intermediate product in the synthesis of 7-methoxy-2,2dimethyl-6-vinylchromone (anhydroencecalinol), a natural product isolated from Flourensia cernua. ${ }^{17}$ The natural products $9 \mathbf{a}$ and $\mathbf{9 b}$ similar to 9 were isolated from Ruta graveolens. ${ }^{18}$

The new natural compounds have structures closely related to those of the isolated coumarins. In fact, all the isolated aromatic compounds including the chalcone $\mathbf{1 4}$ can be joined in a biosynthetic sequence involving the common precursor 4-hydroxy-3-prenylcinnamic acid, which. by a hydroxylation at the 6-position should furnish 2,4-dihydroxy-5-prenylcinnamic acid. Subsequently, 2,4dihydroxy-5-prenylcinnamic acid can undergo a cyclization leading to the coumarins through 7-hydroxy6-prenylcoumarin (7-hydroxy-6-prenylcoumarin $\rightarrow 2$ and $10 ; 2 \rightarrow 3 ; 10 \rightarrow 6$ and $12 ; 6 \rightarrow 1,4,11$ and $13 ; 4 \rightarrow 5$ ) or, alternatively, an O-methylation at the 2-hydroxyl giving 4-hydroxy-2-methoxy-5-prenylcinnamic acid, which makes the formation of the coumarin lactone ring impossible and may be postulated as the direct precursor of the isolated new natural compounds $\mathbf{7 , 8}$ and 9.

The fact that all isolated aromatic compounds bear a prenyl-unit or prenyl-derived substituent at the carbon corresponding to the 3-position in cinnamic acid, led to the conclusion that 4-hydroxy-3-prenylcinnamic acid should be the common precursor, implicating that the prenylation should precede the formation of the lactone ring. This contrasts with some previous studies on the biosynthesis of furanocoumarins, in which the prenylation was considered to occur only after the coumarin lactone ring was formed. ${ }^{19,20}$ In the most recent study on this subject it was shown that umbelliferone in Apium graveolens is prenylated and that this prenylation is achieved via the novel mevalonate independent pathway. ${ }^{19}$ It remains to be investigated if in Brosimum the biosynthesis is different, as was suggested by the results presented here. 


\section{Experimental Section}

\section{General}

NMR spectra in $\mathrm{CDCl}_{3}$ or $\mathrm{CD}_{3} \mathrm{SOCD}_{3}$ solvents were recorded at 300, 400, 500 and $600 \mathrm{MHz}$ for ${ }^{1} \mathrm{H}$ and 75, 100, 125 and $150 \mathrm{MHz}$ for ${ }^{13} \mathrm{C}$ on a Varian Unit Plus 300, Bruker Avance DPX 400, Avance 500 or Avance 600 spectrometers, respectively, using TMS as int. standard or by reference to solvent signals $\mathrm{CHCl}_{3}$ at $\delta_{\mathrm{H}} 7.26$ or $\mathrm{CD}_{2} \mathrm{HSOCD}_{3}$ at $\delta_{\mathrm{H}} 2.49$ and ${ }^{13} \mathrm{CDCl}_{3}$ at $\delta_{\mathrm{C}} 77.00$ or ${ }^{13} \mathrm{CD}_{3} \mathrm{SO}^{13} \mathrm{CD}_{3}$ at $\delta_{\mathrm{C}} 39.50$; LRMS was obtained on a GS/MS-QP 5000 or HP 5989 mass spectrometer. The ${ }^{13} \mathrm{C}$ multiplicity was deduced by comparative analysis of the HBBD- and DEPT- ${ }^{13} \mathrm{C}$ NMR spectra. Homonuclear ${ }^{1} \mathrm{H}$ connectivity was determined by ${ }^{1} \mathrm{H}-{ }^{1} \mathrm{H}-\mathrm{COSY}$ spectra. Heteronuclear ${ }^{1} \mathrm{H}$ and ${ }^{13} \mathrm{C}$ connectivity was deduced by ${ }^{13} \mathrm{C}-{ }^{1} \mathrm{H}-\mathrm{COSY}{ }^{1} J_{\mathrm{CH}}$ [spin-spin coupling of carbon and hydrogen via one bond $\left({ }^{1} J_{\mathrm{CH}} 138.0 \mathrm{~Hz}\right)$ and ${ }^{13} \mathrm{C}$ ${ }^{1} \mathrm{H}-\mathrm{COSY}^{-}{ }^{\mathrm{n}} J_{\mathrm{CH}}[\mathrm{n}=2$ and 3 , spin-spin interaction of carbon and hydrogen via two $\left({ }^{2} J_{\mathrm{CH}}\right)$ and three $\left({ }^{3} J_{\mathrm{CH}}\right)$ bonds, optimized for ${ }^{n} J_{\mathrm{CH}}$ of $8.0 \mathrm{~Hz}$. IR spectra with $\mathrm{KBr}$ plates were obtained on a FT-IR Perkin Elmer 1600/1605 spectrometer. Silica gel 60 (70-230 mesh, Merck) and neutral alumine oxide (BDH Laboratory Supplies) were used for column chromatography and silica gel $60 \mathrm{~F}_{254}$ plates (Merck) for TLC.

\section{Plant material}

The roots of a specimen of Brosimum gaudichaudii Trécul., Moraceae family were collected in Araguari, Minas Gerais State, Brazil, in July, 1994, and compared with voucher specimen deposited at the Reserva Florestal da Companhia Vale do Rio Doce (CVRD), Espírito Santo State, Brazil.

\section{Extraction and isolation}

Air-dried and powdered root bark (1.89 kg) was successively extracted at room temperature with $\mathrm{CH}_{2} \mathrm{Cl}_{2}$ followed by $\mathrm{MeOH}$.

The residue ( $24.6 \mathrm{~g}$ ) obtained from the $\mathrm{CH}_{2} \mathrm{Cl}_{2}$ extract was submitted to $\mathrm{CC}$ (silica gel) eluted with a gradient of hexane $/ \mathrm{CH}_{2} \mathrm{Cl}_{2} / \mathrm{MeOH}$ resulting in 12 frs. The fr. 5-8 (5.4 $\mathrm{g})$ was rechromatographed to produce a mixture of psoralen (4), bergapten (5); fr. 9-12 (9.2 g) also was rechromatographed using a gradient of hexane $/ \mathrm{CH}_{2} \mathrm{Cl}_{2} / \mathrm{MeOH}$ to produce 42 fractions Fr. 9 furnished 4 (42.0 mg); 10-2 yielded a mixture of 4 and 5 (4.5 $\mathrm{mg}$ ) and 2',4',4trihydroxy-3',3-diprenylchalcone (14, $11.0 \mathrm{mg})$; 33-38 (2.3 g) afforded 1'-hydroxymarmesin $(\mathbf{6}, 30.0 \mathrm{mg})$ and a mixture of 1',2'-dehydromarmesin (11) and marmesin (10), after rechromatographed on $\mathrm{CC}$ (neutral alumine oxide) eluted with increasing polarity gradient of $\mathrm{CH}_{2} \mathrm{Cl}_{2}-\mathrm{Et}_{2} \mathrm{O} / \mathrm{MeOH}$.

The $\mathrm{MeOH}$ extract (40.5 g) was partitioned using $\mathrm{CH}_{2} \mathrm{Cl}_{2} / \mathrm{MeOH}: \mathrm{H}_{2} \mathrm{O}(2: 1)$ to furnish hydroalcoholic and dichloromethane solutions and a precipitate $(4.1 \mathrm{~g})$. This precipitate was chromatographed on $\mathrm{CC}$ (neutral aluminum oxide) eluted with $\mathrm{CH}_{2} \mathrm{Cl}_{2}$ and $\mathrm{MeOH}$ to afford a mixture of 4 and $5(3.7 \mathrm{~g})$ and $15(6.0 \mathrm{mg})$. The residue obtained of the $\mathrm{CH}_{2} \mathrm{Cl}_{2}$ solution was partitioned using hexane/MeOH (1:1) yielding a hexane fraction and a precipitate $(0.6 \mathrm{~g}$, a mixture of 4 and 5); the residue (4.0 g) obtained of the $\mathrm{MeOH}$ solution was submitted to $\mathrm{CC}$ (neutral alumine oxide) using $\mathrm{CH}_{2} \mathrm{Cl}_{2}, \mathrm{Et}_{2} \mathrm{O}$, EtOAc and $\mathrm{MeOH}$ to furnish 4 fractions. Fr. 1-3 (2.0 g) was rechromatographed on $\mathrm{CC}$ (silica gel) with a gradient of hexane/ $\mathrm{CH}_{2} \mathrm{Cl}_{2} / \mathrm{Et}_{2} \mathrm{O} / \mathrm{MeOH}$ yielding 22 frs. Fr. 1-10 (1.3 g) was submitted to filtration on sephadex $\mathrm{LH}-20$ eluted with $\mathrm{MeOH} / \mathrm{CHCl}_{3}(50-70 \%)$ affording a mixture of $\mathbf{4}$ and $\mathbf{5}(32.0 \mathrm{mg})$ and $\mathbf{1 4}(10 \mathrm{mg})$; $15-20(160.0 \mathrm{mg})$ also submitted to filtration on sephadex LH-20 eluted with $\mathrm{MeOH}$ followed by $\mathrm{CC}$ (silica gel) to yield a mixture of $\mathbf{1 0}$ and $\mathbf{1 1}$ (44.0 mg); 21-22 (160 mg) furnish 6. The fr. 4 was submitted a $\mathrm{CC}$ (silica gel) with gradient of $\mathrm{CH}_{2} \mathrm{Cl}_{2} /\left(\mathrm{CH}_{3}\right)_{2} \mathrm{O} / \mathrm{MeOH}$ to furnish 25 fractions Fr. 20-25 was washed with $\mathrm{MeOH}$ to afford 3-O- $\beta$ glucopyranosilsitosterol (20.0 mg).

The hydroalcoholic fraction was partitioned with EtOAc/n-BuOH. The EtOAc fraction $(660.0 \mathrm{mg}$ ) was chromatographed on $\mathrm{CC}$ (silica gel) with a gradient of $\mathrm{CH}_{2} \mathrm{Cl}_{2} /\left(\mathrm{CH}_{3}\right)_{2} \mathrm{O} / \mathrm{MeOH}$ to furnish a mixture of $\mathbf{4}$ and $\mathbf{5}$. The residue $(7.1 \mathrm{~g})$ of the $n-\mathrm{BuOH}$ fraction was washed with $\mathrm{MeOH}$ to furnish 1'-hydroxy-3'-O- $\beta$-glucopyranosilmarmesin $(13,630.0 \mathrm{mg})$. The remaining solution was evaporated and the residue obtained $(6.3 \mathrm{~g})$ was submitted to partition with EtOAc-EtOH/H $\mathrm{H}_{2} \mathrm{O}(1: 1)$. The EtOAc fraction furnished 3-O- $\beta$-glucopyranosilsitosterol (480.0 mg).

Air-dried and powdered root wood $(2.2 \mathrm{~kg})$ was extracted with $\mathrm{MeOH}$ at room temperature. The residue (19.8 g) obtained was partitioned with $\mathrm{CH}_{2} \mathrm{Cl}_{2} / \mathrm{H}_{2} \mathrm{O}$ (1:1). The $\mathrm{CH}_{2} \mathrm{Cl}_{2}$ fraction (17.8 g) was submitted to on CC (silica gel) with a gradient of hexane/ $\mathrm{CH}_{2} \mathrm{Cl}_{2} / \mathrm{MeOH}$ yielding 35 fractions Fr. 1-14 (1.9 g) showed rich in fatty acid, sitosterol and $\beta$-amyrin. The fractions 23-33 (4.4 g) were submitted to washing with acetone to furnish a residue $(676.0 \mathrm{mg})$; before concentration, the remaining solution furnish a residue $(1.7 \mathrm{~g})$ that was submitted to filtration on sephadex LH-20 eluted with MeOH to furnish 25 fractions. Fr. 6-10 was chromatographed on CC (silica gel) to furnish 6 (87.0 $\mathrm{mg})$, a mixture of 10, $11(5.0 \mathrm{mg})$ and 8-methoxymarmesin 12 (84.0 mg); 11-22 (1.3 g) was resubmitted to filtration on sephadex LH-20 eluted with $\mathrm{MeOH}$ to furnish a mixture 
of cinnamic acids derivatives 7, 8 and $\mathbf{9}(40.0 \mathrm{mg})$. The residue $(676.0 \mathrm{mg})$ was chromatographed on $\mathrm{CC}$ (silica gel) eluted with gradient $\mathrm{CH}_{2} \mathrm{Cl}_{2} / \mathrm{Et}_{2} \mathrm{O} / \mathrm{MeOH}$ followed by filtration on sephadex $\mathrm{LH}-20$ eluted with $\mathrm{MeOH}$ to furnish 6 (53.0 mg), $12(61.0 \mathrm{mg})$ and 3-O- $\beta$-glucopyranosylsitosterol $(80.0 \mathrm{mg})$.

Mixture of marmesin (10) and 1',2'-dehydromarmesin (11)

IR $v_{\max } / \mathrm{cm}^{-1}: 3478,1707,1628,1570,1482,1446$, $1399,1369,1266,1180,1134(\mathrm{KBr}) ;{ }^{1} \mathrm{H}(300 \mathrm{MHz})$ and ${ }^{13} \mathrm{C}$ $\operatorname{NMR}(75)$, in $\mathrm{CDCl}_{3}$, in accordance with literature data; ${ }^{10,12}$ GC/EIMS $m / z$ (int rel) 10: EIMS $m / z$ (int rel): 246 ([M+ $\left.{ }^{+}\right]$, 7.5), $228\left(\left[\mathrm{M}-\mathrm{H}_{2} \mathrm{O}\right], 2\right), 213\left(\left[\mathrm{M}-\mathrm{H}_{2} \mathrm{O}-\mathrm{Me}\right], 13\right), 188$ ([M $\left.\left.-\mathrm{Me}_{2} \mathrm{C}=\mathrm{O}\right], 37\right), 187\left(\left[\mathrm{M}-\mathrm{Me}_{2} \mathrm{C}=\mathrm{O}-\mathrm{H}\right]\right.$ and/or $([\mathrm{M}-$ $\left.\left.\mathrm{Me}_{2} \mathrm{C}-\mathrm{OH}\right], 75\right), 160$ ([M - $\left.\left.\mathrm{Me}_{2} \mathrm{C}=\mathrm{O}-\mathrm{CO}\right], 25\right), 159$ ([M $\left.\mathrm{Me}_{2} \mathrm{C}=\mathrm{O}-\mathrm{H}-\mathrm{CO}\right]$ and/or $\left(\left[\mathrm{M}-\mathrm{Me}_{2} \mathrm{C}-\mathrm{OH}-\mathrm{CO}\right], 12\right), 59$ ([ $\left.\left.\mathrm{Me}_{2} \mathrm{C}^{+}=\mathrm{OH}\right], 100\right) 11: 244\left(\left[\mathrm{M}^{+}\right], 9\right), 229$ ([M - Me ], 40), $\left.187\left(\mathrm{M}-\mathrm{Me}-\mathrm{CH}_{2}=\mathrm{C}=\mathrm{O}\right], 12\right), 43\left(\mathrm{Me}^{-\mathrm{C}^{+}}=\mathrm{O}, 100\right)$.

3'-hydroxy-4'-O-b-glucopiranosylmarmesin (13)

Amorphous powder; Spectral data are in agreement with literature data. ${ }^{14}$

\section{Peracetyl derivative $\mathbf{1 3}$}

Natural product $13(80.0 \mathrm{mg})$ was treated with $\mathrm{Ac}_{2} \mathrm{O}$ $(9.0 \mathrm{~mL})$ and dry pyridine $(1.0 \mathrm{~mL})$ at room temperature. After the usual workup, the crude peracetyl derivative was chromatographed on a silica gel column eluting with increasing polarity of $\mathrm{CH}_{2} \mathrm{Cl}_{2} / \mathrm{EtOAc} / \mathrm{MeOH}$ to furnish the acetate 13a (19.3 mg). Amorphous power, mp 113-118 ${ }^{\circ} \mathrm{C}$; IR $v_{\max } / \mathrm{cm}^{-1}: 1750,1630,1574,1487,1438,1374$, 1227, 1126, $1041(\mathrm{KBr}) ;{ }^{1} \mathrm{H} \mathrm{NMR}\left(300 \mathrm{MHz}, \mathrm{CDCl}_{3}\right): \delta_{\mathrm{H}}$ 6.27 (d, J9.3 Hz, H-3), 7.63 (d, J9.3 Hz, H-4), 7.57 (s, H-5), 6.84 (s, H-8), 6.27 (d, J $6.3 \mathrm{~Hz}, \mathrm{H}-1^{\prime}$ ), 4.50 (d, J $6.3 \mathrm{~Hz}, \mathrm{H}-$ 2'), 1.53 (s, 3H-4'), 1.46 (s, 3H-5'), 4.89 (d, J7.8 Hz, H-1'), 4.98 (dd, J 7.8, 9.6 Hz, H-2”), 5.28 (t, J 9.6 Hz, H-3”), 5.03 (t, J 9.6 Hz, H-4"), 3.74 (m), 4.21 (dd, J 12.3, 5.7 Hz, H6"a), 4.10 (dd, J 12.3, 2.7 Hz, H-6"b), 2.02 (s, Ac), 2.03 (s, Ac), 2.04 (s, Ac), 2.05 (s, Ac) and 2.06 (s, Ac); HBBD- and DEPT- ${ }^{13} \mathrm{C} \mathrm{NMR}\left(75 \mathrm{MHz}, \mathrm{CDCl}_{3}\right): \delta_{\mathrm{C}} 160.58(\mathrm{C}-2), 113.04$ (CH-3), 143.52 (CH-4), 126.43 (CH-5), 123.64 (C-6), 162.03 (C-7), 98.75 (CH-8), 156.88 (C-9), 113.47 (C-10), 71.20 (CH-1'), 90.35 (CH-2'), 78.81 (C-3'), 23.21 ( $^{\prime} \mathrm{CH}_{3}-$ 4'), 22.76 ( $\mathrm{CH}_{3}-5$ '), 95.12 (CH-1"), 71.35 (CH-2”), 72.65 (CH-3"), 68.45 (CH-4”), 71.49 (CH-5”), 62.06 ( $\left.\mathrm{CH}_{2}-6 ”\right)$; EIMS $m / z$ (int rel): 634 ([M] $\left.]^{+}, 4\right), 574$ ([M-AcOH, 5), 331 ([glucopyranosylAc $\left.]^{+}, 15\right), 287$ ([M-OglucopyranosylAc ${ }_{4}$, 8), 271 ([glucopyranosylAc $\left.4-\mathrm{AcOH}]^{+}, 5\right), 245\left(\left[\mathrm{M}-\mathrm{Me}_{2} \mathrm{C}-\right.\right.$
OglucopyranosylAc 4,15$), 227$ ([M-AcOH-OglucopyranosylAc $\left._{4}, 100\right)$.

\section{8-Methoxymarmesin (12)}

${ }^{1} \mathrm{H}(300 \mathrm{MHz})$ and ${ }^{13} \mathrm{C} \mathrm{NMR}(75 \mathrm{MHz})$, in $\mathrm{CDCl}_{3}$, in accordance with literature data; ${ }^{13}$ EIMS $\mathrm{m} / z$ (int rel) 276 $\left([\mathrm{M}]^{+}, 100\right), 258$ ([M- $\left.\left.\mathrm{H}_{2} \mathrm{O}\right], 23\right), 246$ ([M-CH $\left.\left.\mathrm{C}_{2} \mathrm{O}\right], 25\right), 243$ ([M-H $\left.\left.\mathrm{H}_{2} \mathrm{O}-\mathrm{Me}\right], 50\right), 229$ ([M-CH $\left.\left.\mathrm{H}_{2} \mathrm{O}-\mathrm{HO}\right], 20\right), 218$ ([M$\left.\left.\mathrm{Me}_{2} \mathrm{C}=\mathrm{O}\right], 90\right), 217\left(\left[\mathrm{M}-\mathrm{Me}_{2} \mathrm{C}=\mathrm{O}-\mathrm{H}\right]\right.$ and/or $\left[\mathrm{M}-\mathrm{Me}_{2} \mathrm{C}\right.$ $\mathrm{OH}], 85), 190\left(\left[\mathrm{M}-\mathrm{Me}_{2} \mathrm{C}=\mathrm{O}-\mathrm{CO}\right], 83\right), 175\left(\left[\mathrm{M}-\mathrm{Me}_{2} \mathrm{C}=\mathrm{O}-\right.\right.$ $\mathrm{Me}], 22), 59\left(\left[\mathrm{Me}_{2} \mathrm{C}^{+}=\mathrm{OH}\right], 68\right)$.

\section{2',4',4-trihydroxy-3',3-diprenylchalcone (14)}

Oil; IR $v_{\max } / \mathrm{cm}^{-1}: 3396,1626,1491,1369,1245,1104$, 978 (KBr); ${ }^{1} \mathrm{H}(300 \mathrm{MHz})$ and ${ }^{13} \mathrm{C}(75 \mathrm{MHz}) \mathrm{NMR}$, in $\mathrm{CDCl}_{3}$, in accordance with literature data. ${ }^{15}$

Mixture of the cinnamic acid derivatives 3-(7-methoxy2,2-dimethyl-2H-6-chromenyl-6)-(E)-propenoic acid (7), 3(7-methoxy-2,2-dimethyl-2H-6-chromenyl-6)propanoic acid (8) and 3-(6-methoxybenzo[b]furan-5-yl)propanoic acid(9). Amorphous solid; ${ }^{1} \mathrm{H}$ and ${ }^{13} \mathrm{C}$ NMR: Tables 1 and 2.

EIMS: Scheme 1.

\section{3 $\beta$-O- $\beta$-D-glucopyranosylsitosterol}

${ }^{1} \mathrm{H}$ and ${ }^{13} \mathrm{C}$ NMR spectral data, including of the peracetyl derivative, in agreement with literature data. ${ }^{16}$ The natural product $3 \beta-O-\beta$-D-glucopyranosylsitosterol $(16.0 \mathrm{mg})$ was treated with $\mathrm{Ac}_{2} \mathrm{O}(9.0 \mathrm{~mL})$ and dry pyridine $(1.0 \mathrm{~mL})$ at room temperature. After the usual workup, the crude peracetyl derivative was chromatographed on a silica gel column eluting with increasing polarity gradient of $\mathrm{CH}_{2} \mathrm{Cl}_{2} / \mathrm{EtOAc} / \mathrm{MeOH}$ to furnish the peracetyl derivative (19.3 mg), amorphous powder, mp $160-164{ }^{\circ} \mathrm{C}$.

\section{Acknowledgements}

The authors are grateful to $\mathrm{CNPq}$ for a research fellowship, to Conselho Nacional de Desenvolvimento Cientítico e Tecnológico (CNPq), Coordenação de Aperfeiçoamento de Pessoal do Ensino Superior (CAPES), Programa de Apoio ao Desenvolvimento Científico e Tecnológico (PADCT/Financiadora de Estudos e Projetos (FINEP), Fundação de Amparo à Pesquisa do Estado do Rio de Janeiro (FAPERJ) and Fundação Estadual do Norte Fluminense (FENORTE) for financial support, to the "Centro Nacional de Ressonância Magnética Nuclear", Departamento de Bioquímica Medica, UFRJ, for access to 
the NMR facilities, to the "Centro Nordestino de Aplicação e Uso da Ressonância Magnética Nuclear" (Prof. E. R. Silveira and D. E. A. Uchoa), Universidade Federal do Ceará, for 1D and 2D NMR spectra, and to the Núcleo de Pesquisas de Produtos Naturais, UFRJ (Prof. A. J. R. da Silva and M. C. P. H. Lima) for the GC-MS analysis.

\section{References}

1. Vilegas, J. H. Y.; Lanças, F. M.; Vilegas, W.; Pozetti, G. L.; Phytochem. Anal. 1993, 4, 230.

2. Vilegas, W.; Pozetti, G. L.; Vilegas, J. H.Y.; J. Nat. Prod. 1993, $56,416$.

3. Vieira, I. J. C.; Mathias, L.; Monteiro, V. F. F.; Braz-Filho R.; Rodrigues-Filho, E.; Nat. Prod. Lett. 1999, 13, 47.

4. Gupta, A. K.; Anderson, T. F.; J. Am. Acad. Dermat. - Part I 1987, 17, 703.

5. Parrish, J. A.; Fitzpatrick, T. B.; Tanenbaum, L.; Pathak, M. A.; New England J. Med. 1974, 291, 1207.

6. Braz-Filho, R.; Magalhães, A. F.; Gottlieb, O. R.; An. Acad. Brasil. Ciênc. 1970, 42 (Supl.), 139.

7. Braz-Filho, R.; Magalhães, A. F.; Gottlieb, O. R.; An. Acad. Brasil. Ciênc. 1971, 43, 585.

8. Braz-Filho, R.; Magalhães, A. F.; Gottlieb, O. R.; Phytochemistry 1972, 11, 3307.

9. Dewick, P.; Medicinal Natural Products - A Biosynthetic Approach; John Wiley: New York, 1997, p. 134.
10. Breitmaier, E.; Voelter, W.; Carbon-13 NMR Spectroscopy: High-Resolution Methods and Applications in Organic Chemistry and Biochemistry, 3rd ed., VCH: Weinheim, 1987, p. 447.

11. Grande, M.; Aguado, M. T.; Mancheño, B.; Piera, F.; Phytochemistry 1986, 25, 505.

12. Quader, M. A.; El Turbi, J. A.; Armstrong, J. A.; Gray, A. I.; Waterman, P. G.; Phytochemistry 1992, 31, 3083.

13. Sharma, B. R.; Rattan, R. K.; Sharma P.; Phytochemistry 1980, 19,1556

14. Lemmich, J.; Havelund, S.; Thastrup, O.; Phytochemistry 1983 , 22, 553.

15. Christensen, S. B.; Ming, C.; Anderson, L.; Hjorne, U.; Olsen, C. E.; Cornett, C.; Theander, T. G.; Kharazmi, A.; Planta Med. 1994, 60, 121.

16. Pessoa, O. D. L.; De Lemos, T. L. G.; De Carvalho, M. G.; Braz-Filho, R.; Phytochemistry 1995, 40, 1777.

17. Naidu, M.V.; Rao, G.S.K.; Indian J. Chem., Sect. B $\mathbf{1 9 8 0 ,}$ $19 B, 313$

18. Chen, C-C.; Huang, Y-L.; Huang, F-I.; Wang, C-W.; Ou, JC.; J. Nat. Prod. 2001, 64, 990.

19. Stanjek, V.; Piel, J.; Boland, W.; Phytochemistry 1999, 50, 1141.

20. Brown, S.A.; Steck, W.; Phytochemistry 1973, 12, 1315.

Received: September 20, 2000

Published on the web: March 18, 2002 